Macmillan Building and Surveying Series

Series Editor: Ivor H. Seeley

Emeritus Professor, Nottingham Trent University

Advanced Building Measurement, second edition Ivor H. Seeley

Advanced Valuation Diane Butler and David Richmond

Applied Valuation Diane Butler

Asset Valuation Michael Rayner

Building Economics, third edition Ivor H. Seeley

Building Maintenance, second edition Ivor $\mathrm{H}$. Seeley

Building Maintenance Technology Lee How Son and George C.S. Yuen

Building Procurement Alan E. Turner

Building Project Appraisal Keith Hutchinson

Building Quantities Explained, fourth edition Ivor H. Seeley

Building Surveys, Reports and Dilapidations Ivor H.Seeley

Building Technology, fifth edition Ivor H. Seeley

Civil Engineering Contract Administration and Control, second edition Ivor $\mathrm{H}$.

Seeley

Civil Engineering Quantities, fifth edition Ivor H. Seeley

Civil Engineering Specification, second edition Ivor H. Seeley

Commercial Lease Renewals - A Practical Guide Philip Freedman and Eric F.

Shapiro

Computers and Quantity Surveyors A.J. Smith

Conflicts in Construction - Avoiding, managing, resolving Jeff Whitfield

Construction Contract Claims Reg Thomas

Construction Law Michael F. James

Contract Planning and Contract Procedures, third edition B. Cooke

Contract Planning Case Studies B. Cooke

Cost Estimates of Structures in Commercial Buildings Surinder Singh

Design-Build Explained D.E.L. Janssens

Development Site Evaluation N.P. Taylor

Environment Management in Construction Alan Griffith

Environmental Science in Building, third edition R. McMullan

European Construction-Building techniques and procedures B. Cooke and G.

Walker

Greener Buildings - Environmental impact of property Stuart Johnson

Housing Associations Helen Cope

Housing Management - Changing Practice Christine Davies (Editor)

Information and Technology Applications in Commercial Property Rosemary Feenan and Tim Dixon (Editors)

Introduction to Building Services, second edition Christopher A. Howard and Eric F. Curd

Introduction to Valuation, third edition D. Richmond

Marketing and Property People Owen Bevan

continued overleaf 
Principles of Property Investment and Pricing, second edition W.D. Fraser Project Management and Control David Day

Property Valuation Techniques David Isaac and Terry Steley

Public Works Engineering Ivor H. Seeley

Resource Management for Construction M.R. Canter

Quality Assurance in Building Alan Griffith

Quantity Surveying Practice Ivor H. Seeley

Recreation Planning and Development Neil Ravenscroft

Resource and Cost Control in Building Mike Canter

Small Building Works Management Alan Griffith

Structural Detailing, second edition P. Newton

Urban Land Economics and Public Policy, fourth edition P.N. Balchin, J.L.

Kieve and G.H. Bull

Urban Renewal - Theory and Practice Chris Couch

1980 JCT Standard Form of Building Contract, second edition R.F. Fellows

\section{Series Standing Order}

If you would like to receive future titles in this series as they are published, you can make use of our standing order facility. To place a standing order please contact your bookseller or, in case of difficulty, write to us at the address below with your name and address and the name of the series. Please state with which title you wish to begin your standing order. (If you live outside the United Kingdom we may not have the rights for your area, in which case we will forward your order to the publisher concerned.)

Customer Services Department, Macmillan Distribution Ltd Houndmills, Basingstoke, Hampshire, RG21 2XS, England. 


\title{
Conflicts in Construction
}

Avoiding, Managing, Resolving

\author{
Jeff Whitfield
}

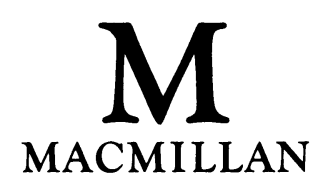


All rights reserved. No reproduction, copy or transmission of this publication may be made without written permission.

No paragraph of this publication may be reproduced, copied or transmitted save with written permission or in accordance with the provisions of the Copyright, Designs and Patents Act 1988, or under the terms of any licence permitting limited copying issued by the Copyright Licensing Agency, 90 Tottenham Court Road, London W1P 9HE

Any person who does any unauthorised act in relation to this publication may be liable to criminal prosecution and civil claims for damages.

First published 1994 by THE MACMILLAN PRESS LTD

Houndmills, Basingstoke, Hampshire RG21 2XS

and London

Companies and representatives

throughout the world

ISBN 978-0-333-60671-1

ISBN 978-1-349-13360-4 (eBook)

DOI 10.1007/978-1-349-13360-4

A catalogue record for this book is available from the British Library 


\section{Contents}

Preface vi

1 Conflicts in Construction 1

2 Why Do We Need to Manage Conflict? 10

3 Causes of Conflict: Interests 18

4 Internal Conflict 31

5 Interpersonal Relationships 47

6 Anatomy of a Construction Project 62

7 Twelve Steps for Reducing Conflict 73

8 Red ' cing Conflict $\quad 91$

9 Managing Conflicts $\quad 105$

10 Informal Resolution Methods 117

11 Formal Dispute Resolution 136

12 Conflict in the 21st Century 149

$\begin{array}{ll}\text { Index } & 157\end{array}$ 


\section{Preface}

To a significant extent the characteristics and consequences of conflict impact on us every day. The influences of conflict can be felt in the family, the workplace, in politics and in our religions. Beyond these external situations we can also find character-building internal conflicts within our very being. We live with conflict every day whether we are alone on a desert island or a part of a large team negotiating a significant new contract.

Any book that deals with the control or management of conflict must, therefore, inevitably deal with five basic fundamentals:

1) The Recognition of Conflict

2) The Avoidance of Conflict

3) The Limitation of Damage Caused by Conflict

4) The Control of Unavoidable Conflict

5) The Resolution of Intractable Conflict.

While the techniques of managing conflict in the home or at work are similar, and many of the behaviours interchangeable, conflict within construction covers such a diverse range of issues that it deserves to be addressed specifically and in depth.

The construction industry comprises a wide diversity of interests, professions and procedures which theoretically interact to create a completed project. All of those involved may share a common goal, but inevitably they have differing and often divergent purposes. The likelihood of disharmony and contention is great.

This work is intended to guide students and practitioners alike through the maze of conflictive behaviours and to suggest some solutions. Where solutions are not available and a painful conflict is inevitable, we prescribe suitable analgesics to reduce the effects of the trauma.

In this book you will be invited to identify the differing meanings of conflict and to understand the causes of each defined meaning. By 
this process you will be able to apply the appropriate technique for the elimination, reduction, management or resolution of that conflict. Because we are all human beings, and because our lives are peppered with conflicts, much of what you read will be familiar. When you have completed the book you should be ready to address the old and familiar conflicts with new vigour and face new conflicts with enthusiasm and imagination.

Jeff Whitfield 